\title{
Quality of life using the EQ-5D-5L and the features of its dynamics among the orthopedic profile patients in outpatient program of physical therapy
}

\author{
S. M. Fedorenko ${ }^{1, A, B, D, E}$, V. V. Vitomskyi ${ }^{1, A, C, D, E}$, 0. B. Lazarieva ${ }^{1, A, D, E}$, \\ E. Yu. Doroshenko $\mathbb{D}^{\star 2, A, D, E}$, M. V. Vitomska ${ }^{1, C, D, E}, \mathrm{I}$. V. Onopriienko ${ }^{1, D, E}$ \\ ${ }^{1}$ National University of Ukraine on Physical Education and Sport, Kyiv, ${ }^{2}$ Zaporizhzhia State Medical University, Ukraine
}

A - research concept and design; B - collection and/or assembly of data; C - data analysis and interpretation; D - writing the article; $\mathrm{E}$ - critical revision of the article; $\mathrm{F}$ - final approval of the article

Aim. To define the quality of life in outpatients with the orthopedic profile disorders and to study its dynamics during the physical
therapy course depending on the disorder localization and psychotype.

Material and methods. The study involved 113 patients enrolled in a course of physical therapy at FESCO Medical Center in 2013-2015. Patients were grouped by the disorder localization and psychotype of the disease. The quality of life assessment was performed using the EQ-5D-5L questionnaire. The course of physical therapy consisted of 12-15 sessions (40-60 minutes; therapeutic physical exercises and mechanotherapy according to a complex ordered by a doctor), physiotherapy (magnetic therapy, electromyostimulation as instructed) and massage (7-8 procedures). The course duration was 5-6 weeks.

Results. Statistically worse initial results were found in patients with lumbar disorders, disorders in the pelvic girdle and the lower extremity on the "mobility", "pain/discomfort", and EQ-VAS scales compared with patients who had upper-body disorders. Differences in "anxiety/depression" and EQ-VAS scales were obtained when dividing patients according to a psychotype. In patients with rational disease perception, the analysis of dynamics revealed better changes and final results on the "anxiety/depression" scale compared with the group of irrational psychotypes. The dynamics on other scales also showed benefits in patients with rational disease perception, although no significant.

Conclusions. The data obtained indicate that not only localization but also features of disease perception affect the quality of life and the effectiveness of physical therapy. The prospects for further research are identifying directions to improve the dynamics through the introduction of new physical therapy tools and methods of their use as well as techniques of managing the physical therapy process.
Key words: physical rehabilitation, therapeutic exercises, activity, patient participation, functioning, musculoskeletal disorders.

Zaporozhye medical journal 2020; 22 (3), 315-322

*E-mail: doroe@ukr.net

\section{Якість життя за EQ-5D-5L та особливості ї̈ динаміки в пацієнтів ортопедичного профікю амбулаторної програми фізичної терапії}

\section{С. М. Федоренко, В. В. Вітомський, О. Б. Аазарєва, Е. Ю. Аорошенко, М. В. Вітомська, І. В. Онопріенко}

Мета роботи - визначити рівень якості життя в амбулаторних пацієнтів із порушеннями ортопедичного профілю та дослідити її динаміку за курс фізичної терапії залежно від локалізації порушення та психотипу.

Матеріали та методи. У досліджені взяли участь 113 пацієнтів, котрі надходили на курс фізичної терапії в медичному центрі «ФЕСКО» впродовж 2013-2015рр. Пацієнтів групували за локалізацією порушення та психотипом ставлення до хвороби. Якість життя оцінювали за опитувальником EQ-5D-5L. Курс фрізичної терапії складався 3 12-15 занять (40-60 хB; терапевтичні фрізичні вправи та механотерапія за комплексом, що призначений лікарем), фізіопроцедур (магнітотерапія, електроміостимуляція за призначенням лікаря) та масажу (7-8 процедур). Тривалість курсу - 5-6 тижнів.

Результати. Виявили статистично гірші початкові результати в пацієнтів із порушеннями в попереку, поясі нижньої кінцівки та самої вільної кінцівки у шкалах «мобільність», «біль/дискомфорт» іВАШ порівняно з пацієнтами з порушеннями у верхній частині тіла. Під час поділу пацієнтів залежно від психотипу отримали відмінності у шкалах «тривога/депресія» та ВАШ. У пацієнтів із раціональним ставленням до хвороби аналіз показав кращу динаміку та остаточні результати за шкалою «тривога/депресія» порівняно з групою нераціональних психотипів. У динаміці за іншими шкалами також спостерігали перевагу в пацієнтів із раціональним ставленням до хвороби, але вони не були вірогідними.

Висновки. Результати свідчать: не тільки локалізація, але й особливості ставлення до хвороби впливають на якість життя та результативність фізичної терапії. Перспективи дальших досліджень полягають у визначенні шляхів покращення динаміки шляхом впровадження нових засобів фізичної терапії та методик їхнього використання, методів управління процесом фрізичної терапії.
Кнючові слова:

фізична реабімітація, мікувальні вправи, активність, участь хворого, функціонування, порушення опорнорухового апарату.

Запорізький медичний журнал. 2020. T. 22, № 3(120) C. 315-322

\section{Качество жизни по EQ-5D-5L и особенности его динамики среди пациентов ортопедического профиля амбулаторной программы физической терапии}

\section{С. Н. Федоренко, В. В. Витомский, Е. Б. Аазарева, Э. Ю. Аорошенко, М. В. Витомская, И. В. Оноприенко}

Цель работы - определить уровень качества жизни у амбулаторных пациентов с нарушениями ортопедического профиля и исследовать его динамику за курс физической терапии в зависимости от локализации нарушения и психотипа. 
Ключевые слова: физическая реабилитация, мечебная гимнастика, Аеятельность, участие больного, функционирование, опорноАвигательные нарушения.

\section{Запорожский} медицинский журнал. 2020. T. 22, № 3(120). C. $315-322$

Материалы и методы. В исследовании приняли участие 113 пациентов, которые поступали на курс физической терапии в медицинском центре «ФЕСКО» в течение 2013-2015 гг. Пациентов группировали по локализации нарушения и психотипу отношения к болезни. Качество жизни оценивали по опроснику EQ-5D-5L. Курс физической терапии состоял из 12-15 занятий (40-60 мин; терапевтические физические упражнения и механотерапия по комплексу, назначенному врачом), физиопроцедур (магнитотерапия, электромиостимуляция по назначению врача) и массажа (7-8 процедур). Продолжительность курса - 5-6 недель.

Результаты. Установлены статистически худшие начальные результаты у пациентов с нарушениями в пояснице, поясе нижней конечности и самой свободной конечности в шкалах «мобильность», «боль/дискомфорт» и ВАШ по сравнению с пациентами с нарушениями в верхней части тела. При разделении пациентов в зависимости от психотипа получены различия по шкалам «тревога/депрессия» и ВАШ. У пациентов с рациональным отношением к болезни анализ динамики показал лучшую динамику и заключительные результаты по шкале «тревога/депрессия» по сравнению с группой нерациональных психотипов. В динамике по другим шкалам также отмечены преимущества у пациентов с рациональным отношением к болезни, однако они не были достоверными.

Выводы. Результаты свидетельствуют, что не только локализация, но и особенности отношения к болезни влияют на качество жизни и результативность физической терапии. Перспективы дальнейших исследований заключаются в определении путей улучшения динамики за счет внедрения новых средств физической терапии и методик их использования, методов управления процессом физической терапии.

Musculoskeletal diseases and injuries, including rheumatic fever, are a major cause of disability $[12,18,19]$. In the World Health Organization Global Burden of Disease Study (2010), back pain was the main cause of people's limited capabilities for many years, neck pain was the fourth cause, and other musculoskeletal disorders ranked fifth. This rating has increased the importance of osteoarthritis, namely, it advanced from the 15th place in 1990 to the 11th in 2010 among the population in Western Europe [19].

Musculoskeletal disorders affect people by limiting their activity and participation [10], as well as society due to cases of job loss, economic impact (disability pensions, early retirement) and the increasing need for social support [6]. However, an obstacle to defining these diseases as a priority for the public health officials is that they are not considered to be fatal [9].

Musculoskeletal disorders are such an important component of human disease in working-age and geriatric populations that good statistics about these disorders are important for health care planning [8]. At the same time, the study on the dynamics of health-related life quality in the field of physical therapy is one of the key points in determining the effectiveness, and the study on the dynamics of recovery depending on the musculoskeletal system area and patient perception of the disease is a condition for qualitative changes in the content of physical therapy programs and the features of managing the physical therapy process [14].

\section{Aim}

The purpose was to define the quality of life in outpatients with the orthopedic profile disorders and to study its dynamics during the physical therapy course depending on the disorder localization and psychotype.

\section{Materials and methods}

The life quality assessment was performed using the international standardized questionnaire EQ-5D-5L [13]. The questionnaire consists of 2 parts. The first part presents 5 (five) sections that give an opportunity: to outline the problems associated with the possibility of moving in space (mobility); self-care, usual activities; to assess the patient's ability to perform work, including housework, study, person's involvement in family or leisure activities; to determine the presence of pain or discomfort, as well as individual psychological problems at the individual level $[1,2]$. These 5 (five) sections include: "Mobility"; "Self-care"; "Usual activities"; "Pain /discomfort"; "Anxiety/depression".

The new version of the EQ-5D-5L questionnaire differs from the previous one in option to rate each section on a 5 -point scale: from no problem (1 point) to its extreme severity (5 points) [2]. The second part of the questionnaire is the EQ visual analogue scale (EQ VAS). It is a $20 \mathrm{~cm}$ vertical graduated line, on which " 0 " means the worst, and " 100 " - the best state of health $[1,2]$. The questionnaire is filled in by respondents or patients on their own in 2-3 minutes, which is usually not difficult for them. Assessment of health status and quality of life (QOL) was performed at the time of the assessment [2].

Patients were grouped using the International Classification of Functioning (ICF). The technique of determining types of the disease perception [16] was used to test the suggestion about a patient's personality influence on the physical therapy effectiveness. Thus, illness was the second factor in grouping patients. It is worth noting that the standard course of physical therapy consisted of 12-15 sessions with a specialist in physical rehabilitation/physical therapist (40-60 minutes; therapeutic exercise and mechanotherapy according to the complex prescribed by a doctor), physiotherapy (magnetotherapy, electromyostimulation according to the medical prescription) and massage (7-8 procedures). The duration of the course was 5-6 weeks.

The study involved 113 patients enrolled in the course of physical therapy at FESCO Medical Center during 2013-2015.

According to the results of the ICF use, it was determined that patients should have been grouped according to their affected structure. Thus, G1 included patients with the following ICF codes: 5740 - pelvic girdle structure; s750 - lower extremity structure; s760 - trunk structure. G2 included patients with ICF codes: s710 - head and neck structures; s720 - shoulder girdle structure; s730 - upper limb structure.

The decision of such division and grouping was also justified by the fact that, according to the component of ICF function, all patients had similar codes. In particular 
b710 - joint mobility function; b715 - joint stability function; b730 - muscle strength function; b735 - muscle tone function; b740 - muscular endurance function. However, only $\mathrm{G} 1$ patients were characterized by the b770 code of the walking stereotype function.

When considering the activities and participation, namely the sections "mobility", "self-care", "housework", it was concluded that the usage of the shoulder girdle, the upper extremity itself, as well as the trunk, pelvis and lower extremity was required for most types of activities. Therefore, the possible differences between the groups should have been carefully examined.

Based on these views on grouping patients, 55 patients were referred to the $\mathrm{G} 1$ and 58 patients - to $\mathrm{G} 2$.

The methodology for determining types of the disease perception was used to test the suggestion about a patient's personality influence on the physical therapy effectiveness, rehabilitation and patient satisfaction [16].

According to the literature data $[3,7]$, namely concerning the classification of the harmonic, ergopathetic and anosognostic types of the rational reaction, the total sample was divided into $\mathrm{G}+(\mathrm{n}=58$, rational types of reaction to the disease) and $\mathrm{G}-(\mathrm{n}=55$, "irrational") and $\mathrm{G} 1$ and G2 - into subgroups by psychotypes. Thus, G1+ and G2+ included rational types of reaction to the disease. In particular, G1+ included 28 patients ( $50.9 \%$ of G1), and G2+ included 30 patients ( $51.7 \%$ of $\mathrm{G} 2$ ). Others were included in $\mathrm{G} 1$ - and G2-.

The materials of the study were processed in program of statistical analysis IBM SPSS 21. Mathematical processing of numerical data was performed with the help of variation statistics. Shapiro-Wilk test (W) was used to analyze the normality of quantitative indicators distribution. For quantitative indicators with normal distribution we found the mean value (x) and square deviation (S). For non-normally distributed quantitative indicators, we found median (Me), quartiles ( $25 \% ; 75 \%$ ), $x$ and S. A significance of differences was assessed with Student's t-test (for independent or dependent groups providing normal distribution of the study results). For indicators with non-normal distribution, we used Wilcoxon's criterion (for dependent groups) and Mann-Whitney U-test (for independent groups).

\section{Results}

Analysis of the QOL in groups of patients by location. It should be noted that according to the statistical analysis results of the EQ-5D-5L questionnaire data, significant differences between $\mathrm{G} 1$ and $\mathrm{G} 2$ groups which were obtained through localization of musculoskeletal disorders, were defined in three scales. Given that, the results on all scales did not correspond to the normal distribution in groups, in Table $1, \mathrm{Me}(25 ; 75)$ and $\overline{\mathrm{x}} \pm \mathrm{S}$ were presented. The distribution was taken into account in the comparison of the results between the groups.

The first scale of the EQ-5D-5L questionnaire is "mobility" (it reflects the level of difficulty in walking). Low scores on this scale reflect the absence of walking difficulties. Assessment analysis of the "mobility" scale (Table 1) revealed Me $(25 ; 75)$ in $\mathrm{G} 1$ at the level of $3(3 ; 4)$ points, and the average result was $3.18 \pm 0.67$ points; and in $\mathrm{G} 2-1(1 ; 1)$ score and $1.14 \pm 0.39$, respectively. The results obtained in the groups
Table 1. EQ-5D-5L quality of life indicators in groups of orthopedic profile patients depending on the disorder localization, points

\begin{tabular}{|c|c|c|c|}
\hline \multirow[t]{2}{*}{ QOL indicators } & & \multicolumn{2}{|l|}{ Groups } \\
\hline & & G1 $(n=55)$ & G2 $(n=58)$ \\
\hline \multirow[t]{2}{*}{ Mobility } & $\operatorname{Me}(25 ; 75)$ & $3(3 ; 4)$ & $1(1 ; 1)^{\star *}$ \\
\hline & $\bar{x} \pm S$ & $3.18 \pm 0.67$ & $1.14 \pm 0.39$ \\
\hline \multirow[t]{2}{*}{ Self-care } & $\operatorname{Me}(25 ; 75)$ & $3(3 ; 4)$ & $3(3 ; 4)$ \\
\hline & $\bar{x} \pm S$ & $2.89 \pm 1.08$ & $3.33 \pm 0.51$ \\
\hline \multirow[t]{2}{*}{ Usual activities } & $\operatorname{Me}(25 ; 75)$ & $3(3 ; 3)$ & $3(3 ; 3.25)$ \\
\hline & $\bar{x} \pm S$ & $3.02 \pm 0.68$ & $3.02 \pm 0.69$ \\
\hline \multirow[t]{2}{*}{ Pain/discomfort } & $\operatorname{Me}(25 ; 75)$ & $4(3 ; 5)$ & $3(3 ; 4)^{\star *}$ \\
\hline & $\bar{x} \pm S$ & $3.87 \pm 0.88$ & $3.10 \pm 0.64$ \\
\hline \multirow[t]{2}{*}{ Anxiety/depression } & $\operatorname{Me}(25 ; 75)$ & $3(2 ; 3)$ & $2.5(2 ; 3)$ \\
\hline & $\bar{x} \pm S$ & $2.75 \pm 0.82$ & $2.59 \pm 0.70$ \\
\hline \multirow[t]{2}{*}{ EQ VAS } & $\operatorname{Me}(25 ; 75)$ & $55(45 ; 65)$ & $60(50 ; 70)^{*}$ \\
\hline & $\bar{x} \pm S$ & $53.91 \pm 12.27$ & $58.53 \pm 12.46$ \\
\hline
\end{tabular}

*: the difference in the indicators between groups is statistically significant $P<0.05 ; * *: P<0.01$.

differed significantly $(P<0.01)$. Thus, it can be argued that the "mobility" indicator was better in $\mathrm{G} 2$.

The limitations of self-care are reflected in the eponymous scale in the EQ-5D-5L questionnaire. Thus, in diseases and after injuries of the musculoskeletal system among patients entering the course of physical therapy at the outpatient stage, the possibilities of self-care did not meet the maximum. In particular, on the self-care scale in the groups $\mathrm{G} 1$ and D2, the indicators of $\mathrm{Me}(25 ; 75)$ were 3 (3; 4), and the indicators of $\bar{X} \pm S$ were slightly better in $G 1$ and amounted to $2.89 \pm 1.08$ points and $3.33 \pm 0.51$ points, respectively. However, no statistical difference was defined $(P>0.05)$ between the groups on this scale.

Disorders and injuries of the musculoskeletal system affect the level of daily activities. Therefore, patients with these conditions can not fully perform normal activities, which affects the deterioration of the "usual activities" of EQ-5D-5L questionnaire scale. This scale is a subjective assessment of a patient's degree of restriction in work, study, work at home, involvement in family affairs, leisure. The closer the index is to one, the better the result and less limited. The obtained statistical indicators in G1 and G2 did not differ significantly $(P>0.05)$, and the indicators of $\mathrm{Me}$ $(25 ; 75)$ on the scale "usual activities" were $3(3 ; 3)$ points and $\bar{x} \pm S$ were $3.02 \pm 0.68$ points in the general sample.

The next scale of the EQ-5D-5L questionnaire is "pain/ discomfort", which reflects the severity of pain and discomfort. Low scores on this scale reflect their absence. An analysis of the "pain/discomfort scale" (Table 1) revealed $\mathrm{Me}(25 ; 75)$ in $\mathrm{G} 1$ at the level of $4(3 ; 5)$ points, and the average result was $3.87 \pm 0.88$ points; and in $\mathrm{G} 2-3(3 ; 4)$ scores and $3.10 \pm 0.64$, respectively. The results obtained in the groups differed significantly $(P<0.01)$.

The "anxiety/depression" level in the EQ-5D-5L questionnaire is determined by the eponymous scale. Thus, on the "anxiety/depression" scale in the groups G1 and G2, the indicators of $\mathrm{Me}(25 ; 75)$ were $3(2 ; 3)$ points and $2.5(2$; 3 ) points, and the indicators of $\bar{x} \pm S$ were $2.75 \pm 0.82$ points and $2.59 \pm 0.70$ points, respectively. There was no statistical difference between the groups on this scale $(P>0.05)$.

On the EQ VAS scale of the EQ-5D-5L questionnaire, which reflects a subjective health assessment at the time of completion, a statistically significant difference $(P<0.05)$ was found between groups $\mathrm{G} 1$ and $\mathrm{G} 2$. So, group $\mathrm{G} 2$ 
Table 2. EQ-5D-5L quality of life indicators in groups of patients depending on the psychotype, points

\begin{tabular}{|c|c|c|c|}
\hline \multirow[t]{2}{*}{ QOL indicators } & & \multicolumn{2}{|l|}{ Groups } \\
\hline & & $G+(n=58)$ & $G-(n=55)$ \\
\hline \multirow[t]{2}{*}{ Mobility } & $\operatorname{Me}(25 ; 75)$ & $2(1 ; 3)$ & $2(1 ; 3)$ \\
\hline & $\bar{x} \pm S$ & $2.07 \pm 1.15$ & $2.20 \pm 1.18$ \\
\hline \multirow[t]{2}{*}{ Self-care } & $\operatorname{Me}(25 ; 75)$ & $3(3 ; 4)$ & $3(3 ; 4)$ \\
\hline & $\bar{x} \pm S$ & $3.05 \pm 0.91$ & $3.18 \pm 0.82$ \\
\hline \multirow[t]{2}{*}{ Usual activities } & $\operatorname{Me}(25 ; 75)$ & $3(3 ; 3)$ & $3(3 ; 4)$ \\
\hline & $\bar{x} \pm S$ & $3.00 \pm 0.65$ & $3.04 \pm 0.72$ \\
\hline \multirow[t]{2}{*}{ Pain/discomfort } & $\operatorname{Me}(25 ; 75)$ & $3(3 ; 4)$ & $3(3 ; 4)$ \\
\hline & $\bar{x} \pm S$ & $3.40 \pm 0.88$ & $3.56 \pm 0.83$ \\
\hline \multirow[t]{2}{*}{ Anxiety/depression } & $\operatorname{Me}(25 ; 75)$ & $2(2 ; 3)$ & $3(3 ; 4)^{\star *}$ \\
\hline & $\bar{x} \pm S$ & $2.21 \pm 0.52$ & $3.15 \pm 0.68$ \\
\hline \multirow[t]{2}{*}{ EQ VAS } & $\operatorname{Me}(25 ; 75)$ & $65(55 ; 70)$ & $55(45 ; 60)^{* *}$ \\
\hline & $\bar{x} \pm S$ & $62.07 \pm 11.70$ & $50.18 \pm 10.36$ \\
\hline
\end{tabular}

*: the difference in the indicators between groups is statistically significant $P<0.05$;

$* *: P<0.01$.

Table 3. Statistical differences in groups, taking into account two factors of patient grouping, points

\begin{tabular}{|c|c|c|c|}
\hline \multirow[t]{2}{*}{ QOL indicators } & & \multicolumn{2}{|l|}{ Groups } \\
\hline & & $\mathrm{G} 1+(n=28)$ & $G 2+(n=30)$ \\
\hline \multirow[t]{2}{*}{ Mobility } & $\operatorname{Me}(25 ; 75)$ & $3(3 ; 4)$ & $1(1 ; 1)^{\star *}$ \\
\hline & $\bar{x} \pm S$ & $3.11 \pm 0.69$ & $1.1 \pm 0.4$ \\
\hline \multirow[t]{3}{*}{ Pain/discomfort } & $\operatorname{Me}(25 ; 75)$ & $3(3 ; 5)$ & $3(3 ; 3.25)^{\star \star}$ \\
\hline & $\bar{x} \pm S$ & $3.79 \pm 0.92$ & $3.03 \pm 0.67$ \\
\hline & & G1- $(n=27)$ & $G 2-(n=28)$ \\
\hline \multirow[t]{2}{*}{ Mobility } & $\operatorname{Me}(25 ; 75)$ & $3(3 ; 4)$ & $1(1 ; 1)^{\star *}$ \\
\hline & $\bar{x} \pm S$ & $3.26 \pm 0.66$ & $1.18 \pm 0.39$ \\
\hline \multirow[t]{2}{*}{ Pain/discomfort } & $\operatorname{Me}(25 ; 75)$ & $4(3 ; 5)$ & $3(3 ; 4)^{\star *}$ \\
\hline & $\bar{x} \pm S$ & $3.96 \pm 0.85$ & $3.18 \pm 0.61$ \\
\hline \multirow[t]{2}{*}{ EQ VAS } & $\operatorname{Me}(25 ; 75)$ & $50(40 ; 55)$ & $55(46.3 ; 60)^{*}$ \\
\hline & $\bar{x} \pm S$ & $47.59 \pm 10.23$ & $52.68 \pm 10.05$ \\
\hline
\end{tabular}

*: the difference in the indicators between groups is statistically significant $P<0.05$; *: $P<0.01$.

had better Me $(25 ; 75) 60(50 ; 70)$ scores, with $\bar{x} \pm S$ at $58.53 \pm 12.46$ points, provided that 100 points corresponded to the best possible level of health. And the $\mathrm{G} 1 \mathrm{group}$ had slightly lower Me $(25 ; 75)-55(45 ; 65)$ scores, with $\bar{x} \pm S$ at $53.91 \pm 12.27$ points.

QOL analysis in groups of patients by psychotype. Taking into account the results of the analysis of QOL indicators according to EQ-5D-5L questionnaire, it was agreed to study the data obtained on the presence of significant differences in groups depending on the psychotype. Table 2 shows the results of the comparison between G+ and G-, since the differences between these groups were similar to that when comparing $\mathrm{G} 1+$ with $\mathrm{G} 1$ - and $\mathrm{G} 2$ + with $\mathrm{G} 2-$, and only two of the six scales differed significantly when comparing G1+ and G2+ and three when comparing G1- and $\mathrm{G} 2$-. In addition, the differences identified will be discussed in more detail. The results of the groups were compared based on the distribution.

The statistical analysis revealed no significant differences in the results of the G+ and G- groups on the "mobility" scale $(P>0.05)$. Thus, the indicators of $\mathrm{Me}(25 ; 75)$ in $\mathrm{G}+$ and $\mathrm{G}$ - were similar and amounted to $2(1 ; 3)$ points, but indicators of $\mathrm{x} \pm \mathrm{S}$ were slightly different and amounted to $2.07 \pm 1.15$ points and $2.20 \pm 1.18$ points, respectively. So, the advantage of the $\mathrm{G}+$ group was not significant.
The statistical analysis results on the "self-care" scale were similar; no significant differences in the results of the $\mathrm{G}+$ and $\mathrm{G}-$ groups were detected $(P>0.05)$. However, the indicators of $\mathrm{Me}(25 ; 75)$ and $\bar{X} \pm \mathrm{S}$ in $\mathrm{G}+$ were $3(3 ; 4)$ and $3.05 \pm 0.91$ points, respectively, and these indicators in G-were $3(3 ; 4)$ points and $3.18 \pm 0.82$ points, respectively.

Indicators on the "usual activities" scale were minimally worse in G- and this difference was not sufficient to establish a significant difference between the groups $(p>0.05)$. $\mathrm{Me}(25 ; 75)$ and $\bar{x} \pm S$ in $\mathrm{G}+$ were $3(3 ; 3)$ and $3.00 \pm 0.65$ points, respectively, and these indicators in $\mathrm{G}$ - were 3 (3; 4) and $3.04 \pm 0.72$ points, respectively.

The results obtained on the "pain/discomfort" scale were slightly worse in G-, but this difference was not sufficient to establish the statistical difference between the groups $(P>0.05)$. Thus, the values of $\mathrm{Me}(25 ; 75)$ in $\mathrm{G}+$ and G- were similar and amounted to $3(3 ; 4)$ points, but $\bar{x} \pm S$ were slightly different and amounted to $3.40 \pm 0.88$ points and $3.56 \pm 0.83$ points, respectively. Thus, the advantage of the $\mathrm{G}+$ group was not significant.

A significant difference between G+ and G- was found on the "anxiety/depression" scale. Thus, the score on the scale was better $(P<0.01)$ in $\mathrm{G}+$, and the indicators of $\mathrm{Me}(25 ; 75)$ in $\mathrm{G}+$ and $\mathrm{G}-$ were $2(2 ; 3)$ points and $3(3 ; 4)$ points, respectively. The difference between the average values of the groups was 0.94 points, which was a significant difference when considering the features on the rating scale. Thus, patients with rational perception of the disease had better subjective levels of anxiety and depression.

The statistical difference between $\mathrm{G}+$ and $\mathrm{G}$ - was also obtained on the EQ VAS scale of the EQ-5D-5L questionnaire, which reflects a subjective health assessment at the time of its completion. Thus, the score on the scale was statistically higher $(\mathrm{P}<0.01)$ in $\mathrm{G}+$, and the values of $\mathrm{Me}(25$; $75)$ in $\mathrm{G}+$ and $\mathrm{G}$ - were $65(55 ; 70)$ points and $55(45 ; 60)$ points, respectively, provided that 100 points corresponded to the best possible level of health. The $\bar{x} \pm S$ indicators were $62.07 \pm 11.70$ points and $50.18 \pm 10.36$ points, respectively. The difference between the mean values of the groups was 11.89 points. Thus, patients with rational perception of the disease $(\mathrm{G}+)$ rated their health status better than patients in group $\mathrm{G}-$.

When comparing patients with rational psychotypes, statistical differences were found on the scales of "mobility" $(P<0.01)$ and "pain/discomfort" $(P<0.01)$ between the groups with lesions in the lower $(\mathrm{G} 1+)$ and upper $(\mathrm{G} 2+)$ parts of the body (Table 3). Thus, on the "mobility" scale, Me $(25 ; 75)$ in $\mathrm{G} 1+$ were worse than in $\mathrm{G} 2+$, and the statistical indicators were the following: $3(3 ; 4)$ points in $\mathrm{G} 1+$ and 1 $(1 ; 1)$ point in $\mathrm{G} 2+$. The difference between the mean values of the groups on this scale was 2.01 points, and the $\bar{x} \pm S$ were $3.11 \pm 0.69$ points and $1.1 \pm 0.4$ points, respectively. In addition, the $\mathrm{G} 1+$ group had significantly better "pain/ discomfort" scores: G1+ had $3(3 ; 5)$ and G2+ had 3 (3; 3.25) points $(P<0.01)$. The difference between the mean values of the groups on the "pain/discomfort" scale was 0.76 points, and the $\bar{x} \pm$ S were $3.79 \pm 0.92$ points and $3.03 \pm 0.67$ points, respectively.

When comparing patients with irrational psychotypes, statistical differences were found on the scales "mobility" $(\mathrm{P}<0.01)$, "pain/discomfort" $(\mathrm{P}<0.01)$ and EQ VAS $(P<0.05)$ between groups with lower - $(\mathrm{G} 1-)$ and up- 
per-body (G2-) disorders (Table 3). Thus, on the "mobility" scale, Me $(25 ; 75)$ in $\mathrm{G} 1-$ was worse than in $\mathrm{G} 2-$ : $3(3 ; 4)$ scores in $\mathrm{G} 1-$ and $1(1 ; 1)$ score in $\mathrm{G} 2-(\mathrm{P}<0.01)$. The difference between the average values of the groups on this scale was 2.08 points, and the $\bar{x} \pm S$ were $3.26 \pm 0.66$ points and $1.18 \pm 0.39$ points, respectively. However, the G1- group had significantly worse Me $(25 ; 75)$ "pain/ discomfort" scores: $4(3 ; 5)$ scores among $\mathrm{G} 1-$ patients and $3(3 ; 4)$ scores among the $G 2-$ patients $(P<0.01)$.

The difference in mean values on the "pain/discomfort" scale was 0.78 points, and the $\bar{x} \pm S$ were $3.96 \pm 0.85$ points and $3.18 \pm 0.61$ points, respectively. A statistically significant difference was observed when comparing $\mathrm{G} 1$ - and $\mathrm{G} 2-$ on the EQ VAS scale: $50(40 ; 55)$ points in $\mathrm{G} 1-$ and 55 (46.3; $60)$ points in G2-. So, patients in the G1- group rated their health at a lower level. The difference in the mean values on the EQ VAS scale was 5.09 points, and the $\bar{x} \pm S$ were $47.59 \pm 10.23$ points in $\mathrm{G} 1$ - and $52.68 \pm 10.05$ points in $\mathrm{G} 2$ - .

QOL dynamics analysis in patient groups. Before considering the characteristics of the dynamics in the patient groups with lower-body and lumbar spine disorders (Table 4), we noted that all indicators of the EQ-5D-5L questionnaire had improved significantly over the standard course of physical therapy $(P<0.01)$. Table 4 presents the final indicators of $\bar{x} \pm S$, Me $(25 ; 75)$ and the indicator of change in the average value among the groups with the lower-body disorders according to rational $(\mathrm{G} 1+)$ and irrational (G1-) psychotypes, as well as the final comparison results of indicators taking into account the distribution.

Thus, the "mobility" scale improved statistically in both groups $(P<0.01)$. The average values on the scale in $\mathrm{G} 1$ + and $\mathrm{G} 1-$ were decreased, 0.82 points and 0.63 points, respectively, (Table 4). Accordingly, the difference in the dynamics amounted to 0.19 points, which was $30.2 \%$ of the increase in G1-. However, the changes were not statistically significant in $\mathrm{G} 1+(\mathrm{P}>0.05)$. At the same time, no statistically significant difference was found between the final Me $(25 ; 75)$ values of groups: $2(2 ; 3)$ points in $\mathrm{G} 1+$ and $3(2 ; 3)$ points in $\mathrm{G} 1-(P>0.05)$. So, the difference between the final $\bar{x}$ in $\mathrm{G} 1+$ and $\mathrm{G} 1$ - was increased to 0.34 points.

The particular dynamics on the "self-care" scale in G1+ and G1-groups showed a decrease in the average values, 0.54 points and 0.52 points, respectively. Therefore, the difference between reductions was only 0.02 points, which was $3.8 \%$ of the $\mathrm{G} 1-$ decreasing. There were no statistically significant differences between the group final results of $\mathrm{Me}(25 ; 75)$ on the "self-care" scale: $2(2 ; 3)$ scores in $\mathrm{G} 1+$ and $3(2 ; 3)$ scores in $\mathrm{G} 1-(P>0.05)$. And the difference between the mean values of the final results in groups $\mathrm{G} 1$ + and $\mathrm{G} 1$ - was 0.31 points.

According to the statistical analysis results, the particular dynamics on the "usual activities" scale were such that a decrease in the average values on the scale in $\mathrm{G} 1+$ and G1- was 0.64 points and 0.48 points, respectively. Thus, the difference in dynamics was 0.16 points, which was $33.3 \%$ of the increase in $\mathrm{G} 1-$.

Therefore, the average value dynamics was more expressed in the group with rational psychotypes, but the advantage in this dynamics was not significant $(P>0.05)$. At the same time, no statistically significant difference was found between the final results of $\mathrm{Me}(25 ; 75)$ in the groups according to "usual activities" scale: $2(2 ; 3)$ points in G1+
Table 4. EQ-5D-5L quality of life indicators in repeated surveying the patient groups with lower-body and lumbar spine disorders according to rational $(\mathrm{G} 1+)$ and irrational (G1-) psychotypes, points

\begin{tabular}{l|l|l|l|l} 
QOL indicators & Groups & $\overline{\mathbf{x}} \pm \mathbf{S}$ & $\Delta \mathbf{x}$ & Me $(25 ; 75)$ \\
Mobility & G1+ & $2.29 \pm 0.66$ & -0.82 & $2(2 ; 3)$ \\
& G1- & $2.63 \pm 0.74$ & -0.63 & $3(2 ; 3)$ \\
Self-care & G1+ & $2.21 \pm 0.74$ & -0.54 & $2(2 ; 3)$ \\
& G1- & $2.52 \pm 0.80$ & -0.52 & $3(2 ; 3)$ \\
Usual activities & G1+ & $2.32 \pm 0.67$ & -0.64 & $2(2 ; 3)$ \\
Pain/discomfort & G1- & $2.59 \pm 0.64$ & -0.48 & $3(2 ; 3)$ \\
& G1+ & $2.57 \pm 0.69$ & -1.21 & $3(2 ; 3)$ \\
Anxiety/depression & G1- & $2.89 \pm 0.85$ & -1.07 & $3(2 ; 4)$ \\
& G1+ & $1.21 \pm 0.42$ & -1.04 & $1(1 ; 1)^{* *}$ \\
EQ VAS & G1- & $2.89 \pm 0.42$ & -0.37 & $3(3 ; 3)$ \\
& G1+ & $68.90 \pm 10.03$ & 8.93 & $70(65 ; 75)^{* *}$ \\
\hline
\end{tabular}

*: the difference in the indicators between groups is statistically significant $P<0.05 ; * *$ : $P<0.01$.

and $3(2 ; 3)$ points in $\mathrm{G} 1-(\mathrm{P}>0,05)$. The difference between the average values of the final results in $\mathrm{G} 1+$ and $\mathrm{G} 1-$ was 0.27 points.

The dynamics on the "pain/discomfort" scale showed statistically significant improvements in both groups $(P<0.01)$, as on the previous scales. A decrease in the average values of $\mathrm{G} 1+$ and $\mathrm{G} 1-$ were 1.21 points and 1.07 points, respectively. Thus, the difference in dynamics was 0.14 points. That means, among patients with rational psychotypes, the "pain/discomfort" scale dynamics was better by $13.1 \%$, but the difference in dynamics did not lead to statistical differences in the $\Delta x$ index. In addition, no statistically significant difference was found between the final Me $(25 ; 75)$ in the groups: $3(2 ; 3)$ points in $\mathrm{G} 1+$ and $3(2 ; 4)$ points in $\mathrm{G} 1-(\mathrm{P}>0.05)$. Therewith, the difference between the average values of $\mathrm{G} 1+$ and $\mathrm{G} 1$ - groups increased slightly and amounted to 0.32 points.

The "anxiety/depression" scale, like all the scales, improved statistically in both groups with lower-body disorders $(P<0.01)$. A decrease in average values of $G 1+$ and $\mathrm{G} 1-$ were 1.04 points and 0.37 points, respectively. Accordingly, the difference in the rate of downgrading was 0.67 points, which was $181.1 \%$ of the increase in G1-. It should be noted that the decrease was statistically greater in $\mathrm{G} 1+(\mathrm{P}<0.01)$. From that, among patients with rational psychotypes, the dynamics was significantly almost three times better. However, statistically significant differences were found between the final results of $\mathrm{Me}(25 ; 75)$ in the groups: $1(1 ; 1)$ point and $3(3 ; 3)$ points $(P<0.01)$, respectively.

According to the statistical analysis results, the dynamics on the EQ VAS scale of the EQ-5D-5L questionnaire was significant, as on the previous scales $(P<0.01)$. An increase in the average score in $\mathrm{G} 1+$ and $\mathrm{G} 1$ - was 8.93 and 7.59 , respectively. No differences in $\Delta x$ were found $(P>0.05)$. The difference in growth amounted to only 1.34 points, which was $17.7 \%$ of the increase in G1-. At the same time, statistically significant differences were found between the final results of $\mathrm{Me}(25 ; 75)$ in the groups $\mathrm{G} 1+$ and $\mathrm{G} 1-$ on the EQ VAS scale, and the indicators were $70(65 ; 75)$ points and $55(50 ; 60)$ points $(P<0,01)$, respectively. So, the difference between the average values of the final results in G1+ and G1-groups increased slightly and amounted to 13.7 points. 
Table 5. EQ-5D-5L quality of life indicators in repeated surveying the patient groups with upper-body and lumbar spine disorders according to rational (G2+) and irrational (G2-) psychotypes, points

\begin{tabular}{ll|l|l|l} 
QOL indicators & Groups & $\overline{\mathbf{x}} \pm \mathbf{S}$ & $\Delta \mathbf{x}$ & Me $(25 ; 75)$ \\
\hline Mobility & G2+ & $1.07 \pm 0.25$ & -0.03 & $1(1 ; 1)$ \\
& G2- & $1.14 \pm 0.36$ & -0.04 & $1(1 ; 1)$ \\
Self-care & G2+ & $2.53 \pm 0.63$ & -0.80 & $3(2 ; 3)$ \\
& G2- & $2.68 \pm 0.77$ & -0.64 & $2.5(2 ; 3)$ \\
\hline Usual activities & G2+ & $2.37 \pm 0.76$ & -0.67 & $2(2 ; 3)$ \\
\hline Pain/discomfort & G2- & $2.39 \pm 0.92$ & -0.61 & $2(2 ; 3)$ \\
\hline Anxiety/depression & G2+ & $2.20 \pm 0.48$ & -0.83 & $2(2.00 ; 2.25)^{*}$ \\
& G2- & $2.54 \pm 0.58$ & -0.64 & $3(2 ; 3)$ \\
EQ VAS & G2+ & $1.20 \pm 0.41$ & -0.97 & $1(1 ; 1)^{* *}$ \\
& G2- & $2.54 \pm 0.58$ & -0.50 & $3(2 ; 3)$ \\
\hline
\end{tabular}

*: the difference in the indicators between groups is statistically significant $P<0.05 ; * *$ : $P<0.01$.

Before considering the dynamics among the patient groups with upper-body disorders (Table 5), it should be noted that all the EQ-5D-5L questionnaire scores had improved significantly over the standard physical therapy course $(P<0.01)$, except the "mobility" scale. Table 5 presents the final indicators of $\bar{x} \pm S, M e(25 ; 75)$ and the mean change among groups with upper-body disorders according to rational (G2+) and irrational (G2-) psychotypes, as well as the final results comparison based on the distribution.

Thus, the "mobility" scale did not change significantly in both groups $(P>0.05)$. A decrease in the average values on the scale in $\mathrm{G} 2+$ and $\mathrm{G} 2$ - was insignificant and amounted to 0.03 points and 0.04 points, respectively (Table 5 ). Hence, the difference in the dynamics was minimal.

The particular dynamics on the "self-care" scale in G2+ and G2- groups reflected a 0.80 point and 0.64 point decrease in the average values, respectively. Therefore, the difference in reduction was only 0.16 points, which was $25 \%$ of the increase in G2-. No statistically significant difference was found between the final group results of $\mathrm{Me}(25 ; 75)$ on the "self-care" scale: $3(2 ; 3)$ points in $\mathrm{G} 2+$ and $2.5(2 ; 3)$ points in $G 2-(P>0.05)$. And the difference between the average values of $\mathrm{G} 2+$ and $\mathrm{G} 2-$ final group results was 0.15 points.

According to the statistical analysis results, the particular dynamics on the "usual activities" scale were that a decrease in the average values on the scale in $\mathrm{G} 2+$ and G2- groups was 0.67 points and 0.61 points, respectively. Thus, the difference in dynamics was only 0.06 points, which was $9.8 \%$ of the increase in G2-. Therefore, the dynamics of average value was more pronounced in the group with rational psychotypes, but an advantage of this dynamics was not insignificant $(P>0.05)$. Moreover, no statistically significant difference was found between the final results of $\mathrm{Me}(25 ; 75)$ in the "usual activities" groups: $2(2 ; 3)$ points in $\mathrm{G} 2+$ and $2(2 ; 3)$ points in $\mathrm{G} 2-(\mathrm{P}>0.05)$.

The dynamics on the "pain/discomfort" scale showed statistically significant improvements in both groups $(P<0.01)$, as on the previous scales. A decrease in the average values on the scale reached 0.83 points and 0.64 points in G2+ and G2-, respectively. So, the difference in dynamics was 0.19 points. Besides, among patients with rational psychotypes, the dynamics on the "pain/discomfort" scale was better by $29.7 \%$, but this difference in the dynamics did not lead to statistical differences in the $\Delta \mathrm{x}$ indicator. In addition, statistically significant differences were found between the final $\mathrm{Me}(25 ; 75)$ in the groups: $2(2 ; 2.5)$ points in $\mathrm{G} 2+$ and $3(2 ; 3)$ points in $\mathrm{G} 2-(\mathrm{P}<0.05)$. At the same time, the difference between the mean values of $\mathrm{G} 2+$ and G2- groups increased slightly to 0.34 points.

The "anxiety/depression" scale, like all other scales, improved statistically in both groups with upper-body disorders $(P<0.01)$. A decrease in the average values on the scale was 0.97 points and 0.50 points in $\mathrm{G} 2+$ and G2-, respectively. Accordingly, the difference in reduction was 0.47 points, which was $94 \%$ of the increase in G2-. It should be noted that the decrease was statistically larger in $\mathrm{G} 2+(\mathrm{P}<0.01)$. Thus, in patients with rational psychotypes, the dynamics was significantly better and almost doubled. However, statistically significant differences were found between the group final results of $\mathrm{Me}(25 ; 75): 1(1 ; 1)$ points and $3(2 ; 3)$ points $(P<0.01)$, respectively.

According to the results of the statistical analysis, the dynamics on the EQVAS scale of the EQ-5D-5L questionnaire was as significant as on the previous scales $(P<0.01)$. An increase in average values on scales in $\mathrm{G} 2+$ and $\mathrm{G} 2$ - were 9 points and 8.21 points, respectively. No differences in $\Delta x$ were found $(P>0.05)$. The difference in the increase was only 0.79 points, which was $9.6 \%$ of the increase in G2At the same time, statistically significant differences were found between the final results of Me $(25 ; 75)$ in $\mathrm{G} 2+$ and G2- groups on the EQ VAS scale, and the indicators were $75(67.5 ; 80)$ points and $60(55 ; 70)$ points $(P<0.01)$, respectively. Thus, the difference between the average values of G2 + and G2- final results increased slightly to 9.1 points.

At the same time, it should be noted that comparing the dynamics based on disorders localization, the patients with lower-body disorders showed more pronounced dynamics on the scale of "mobility" and "pain/discomfort"; while patients with upper-body disorders had more pronounced dynamics on the "self-care" scale.

\section{Discussion}

The study revealed differences in the initial results on the "mobility", "pain/discomfort" and EQ VAS scales between G1 and G2 groups (grouped by localization). It should be noted that all these differences confirmed worse results in patients with lumbar, pelvic girdle and the lower extremity disorders. The most pronounced difference was on the scale of "mobility", taking into account the peculiarities of scale assessment. Thus, the assumption about possible differences in the QOL depending on the localization of musculoskeletal disorder was substantiated.

When dividing patients based on the disease characteristics, we obtained statistical differences on the "anxiety/ depression" and EQ VAS scales. It should be noted that the differences on the EQ VAS scale were more pronounced than when dividing groups based on the disorder localization.

Among patients with lower-body and lumbar spine disorders, dynamics analysis revealed statistically better changes and final scores on the "anxiety/depression" scale in $\mathrm{G} 1+$ group compared to the irrational psychotype group (G1-). The dynamics on other scales also showed advantages in $\mathrm{G} 1+$, but they were not significant. In the mean 
time, the difference was significant on the EQ VAS scale between $\mathrm{G} 1+$ and $\mathrm{G} 1-$.

When comparing the final results of $\mathrm{G} 2+$ and $\mathrm{G} 2-$, a significant difference was observed on the "pain/discomfort", "anxiety/depression", and EQ VAS scales. Among patients with upper-body disorders, dynamics analysis revealed statistically better changes on the "anxiety/depression" scale in the group with rational disease perception (G2 +) compared to the group of irrational psychotypes (G2-). The dynamics on other scales also showed advantages in $\mathrm{G} 1+$, which were not significant.

The results of our work supplemented the data on the QOL in musculoskeletal disorders.

Thus, in the study of C. H. Roux and co-authors [15], the QOL dynamics among healthy patients and its change with the musculoskeletal disorders development was examined as well as a comparison of the QOL levels was done. In particular, the study showed the development of spine disorders (neck pain, back pain, disc herniation, osteoporosis (stress fractures)), joint disorders (osteoarthritis, microcrystalline arthritis, and arthritis), and extra-articular disorders (tendonitis, capsulitis and carpal tunnel syndrome).

A noteworthy detail is that the lowest scores were defined on the "viability" and "mental health" scales in all surveys. The authors pointed out that, compared to the control group, patients with disorders had significantly more serious reductions in the following indicators: somatic pain (-7.4 points difference in dynamics), vitality $(-2.7)$, general health $(-1.8)$ and physical functioning $(-1.3)$. In the group of musculoskeletal disorders, chronic disorders had a greater impact than acute on physical functioning $(-2.1)$, role emotional (-8.4), and social functioning (-5.9). However, it should be noted that the figures obtained were significantly lower. At the same time, the results of patients with musculoskeletal disorders presented by Roux C.H. and co-authors, much better than the results of a healthy population in Ukraine [5].

Picavet H. S. J. and Hoeymans N. in their study [11] reported that all diseases of the musculoskeletal system are associated with pain and physical function impairment, and the combination of musculoskeletal system diseases should be considered in studies and clinical practice because of their high occurrence and a significant impact on health-related QOL. At the same time, the authors examined the health-related QOL in healthy people and people with one or more musculoskeletal disorders using the SF-36 and Euroqol (EQ-5D) questionnaires. The sample included Dutch residents aged 25 years $(n=3664)$. Twelve descriptions of common musculoskeletal diseases were presented and the respondents were asked whether they had ever been told by a doctor that they had any of these. Their responses were used to evaluate the prevalence of these conditions. Thus, it was found that people with musculoskeletal disorders had significantly lower scores on all SF-36 scales than those without musculoskeletal disorders, especially for "physical functioning" (75.2 vs. 87,8$)$; "the role of physical problems in limiting life" (67.1 vs. 85.8) and "pain" (68.5 vs. 84.1). The worst health-related quality of life indicators were found were found for osteoarthritis of the hip, osteoporosis, rheumatoid arthritis, and fibromyalgia. Those with multiple musculoskeletal disorders had the worst quality of life. Similar results were found for the EQ-5D questionnaire.
Similar to the previous comparison, our results were also lower than in the work of H. S. J. Picavet and N. Hoeymans [11]. This can be explained by the fact that, as mentioned, the quality of life of a healthy population in Ukraine [5] may be lower than among the population of others with the musculoskeletal disorders. Secondly, respondents with musculoskeletal pathologies in the study of H. S. J. Picavet and N. Hoeymans [11] were a sample of residents, and in our study, patients themselves sought the outpatient physical therapy program or were referred by a physician as they could not endure such pain any longer or due to limited mobility and activity, as is often happens, since the patients reported considerable periods of discomfort and limitations.

At the same time, there are a lot of papers in scientific bases dealing with the problems of quality of life in specific musculoskeletal diseases, but the results of mixed groups are less frequently reported.

\section{Conclusions}

The data obtained indicate that not only localization but also features of disease perception affect the quality of life and the effectiveness of physical therapy. Based on the results obtained in the physical therapy for patients with disorders in the lower body and lumbar part, considerable attention should be paid to their mobility. Special approaches should be applied to a patient in dealing with irrational disease perception, taking into account the higher level of anxiety and EQ VAS, which reflects a subjective assessment of health at the time of completion.

The prospects for further research are identifying directions to improve the dynamics through the introduction of new physical therapy tools and methods of their use as well as techniques of managing the physical therapy process. In particular, developments regarding improvement of the therapeutic alliance formation, patients and staff motivation, identification of ways to improve the quality of physical therapy services. Thus, recent articles $[4,17]$ have been published in this area and further work is underway.

\section{Funding}

The work was carried out in accordance with the plan of research and development of the SDU NUPESU for 2016-2020 on the topic: 4.2. "Organizational and theoretical and methodological foundations of physical rehabilitation of people of different nosological, professional and age groups", state registration number 0116U001609.

Conflicts of interest: authors have no conflict of interest to declare. Конфмікт інтересів: віАсутній.

Надійшла Ао редакції / Received: 21.11.2019

Після Аоопрацювання / Revised: 11.12.2019

Прийнято Ао Аруку / Accepted: 20.12.2019

Information about the authors:

Fedorenko S. M., PhD, Lecturer of the Department of Physical Therapy and Ergotherapy, National University of Ukraine on Physical Education and Sport, Kyiv, Ukraine. ORCID ID: 0000-0002-6266-5361

Vitomskyi V. V., PhD, Lecturer of the Department of Physical

Therapy and Ergotherapy, National University of Ukraine on Physical Education and Sport, Kyiv, Ukraine.

ORCID ID: 0000-0002-4582-6004 
Lazarieva O. B., PhD, DSc, Professor, Head of the Department of Physical Therapy and Ergotherapy, National University of Physical Education and Sport of Ukraine, Kyiv.

ORCID ID: 0000-0002-7435-2127

Doroshenko E. Yu., PhD, DSc, Professor of the Department of Physical Rehabilitation, Sports Medicine, Physical Training and Health, Zaporizhzhia State Medical University, Ukraine.

ORCID ID: 0000-0001-7642-531x

Vitomska M. V., Lecturer of the Department of Physical Therapy and Ergotherapy, Postgraduate student of the Department of Physical Therapy and Ergotherapy, National University of Ukraine on Physical Education and Sport, Kyiv, Ukraine.

ORCID ID: 0000-0002-5163-3954

Onopriienko I. V., Postgraduate Student of the Department of Physical Therapy and Ergotherapy, National University of Ukraine on Physical Education and Sport, Kyiv, Ukraine.

ORCID ID: 0000-0003-0830-1652

\section{Відомості про авторів:}

Федоренко С. М., канА. наук з фізичного виховання та спорту, викладач каф. фізичної терапії та ерготерапії, Національний університет фізичного виховання і спорту України, м. Київ. Вітомський В. В., канА. наук з фізичного виховання та спорту, викладач каф. фізичної терапії та ерготерапії, Національний університет фізичного виховання і спорту України, м. Київ. Лазарєва О. Б., А-р наук з фізичного виховання та спорту, професор, зав. каф. фізичної терапії та ерготерапії,

Національний університет фізичного виховання і спорту України, м. Київ.

Аорошенко Е. Ю., А-р наук із фізичного виховання та спорту, професор каф. фізичної реабілітації, спортивної меАицини, фізичного виховання і зАоров'я, Запорізький Аержавний медичний університет, Україна.

Вітомська М. В., викладач каф. фізичної терапії та ерготерапії, аспірант каф. фізичної терапії та ерготерапії, Національний університет фізичного виховання і спорту України, м. Київ. Онопрієнко І. В., аспірант каф. фізичної терапії та ерготерапії, Національний університет фізичного виховання і спорту України, м. Київ.

\section{Сведения об авторах:}

Федоренко С. М., канА. наук по физическому воспитанию и спорту, преподаватель каф. физической терапии и эрготерапии, Национальный университет физического воспитания и спорта Украины, г. Киев.

Витомский В. В., канА. наук по физическому воспитанию и спорту, преподаватель каф. физической терапии и эрготерапии, Национальный университет физического воспитания и спорта Украины, г. Киев.

Аазарева Е. Б., А-р наук по физическому воспитанию и спорту, профессор, зав. каф. физической терапии и эрготерапии, Национальный университет физического воспитания и спорта Украины, г. Киев.

\section{Аорошенко Э. Ю., А-р наук по физическому воспитанию и} спорту, профессор каф. физической реабилитации, спортивной медицины, физического воспитания и зАоровья, Запорожский государственный меАицинский университет, Украина. Витомская М. В., преподаватель каф. физической терапии и эрготерапии, аспирант каф. физической терапии и эрготерапии, Национальный университет физического воспитания и спорта Украины, г. Киев.

Оноприенко И. В., аспирант каф. физической терапии и эрготерапии, Национальный университет физического воспитания и спорта Украины, г. Киев.

\section{References}

[1] Akulova, A. I., Gaydukova, I. Z., \& Rebrov, A. P. (2018). Validatsiya versii 5 L oprosnika EQ-5D v Rossii [Validation of the EQ-5D-5L version in Russia]. Nauchno-prakticheskaya revmatologiya, 56(3), 351-355. https://doi.org/10.14412/1995-4484-2018-351-355 [in Russian].

[2] Amirdjanova, V. N. \& Erdes, S. F. (2007). Validatsiya russkoiversii obshchego oprosnika EuroQol-5D (EQ-5D) Nalidation of general questionnaire EuroQol-5D (EQ-5D) Russian version]. Nauchno-prakticheskaya revmatologiya, 45(3) 69-76. https://doi.org/10.14412/1995-4484-2007-691 [in Russian].

[3] Chernov, A. (2014, October 18). 12 patsientov i ikh psikhotipy [12 patients and their psychotypes]. Katrenstil'. https://www.katrenstyle. ru/articles/journal/medicine/ethics/12 patsientov i in psihotipyi. [in Russian].

[4] Fedorenko, S., Vitomskyi, V., Lazarieva, O., \& Vitomska, M. (2019). Upravlinnia ta motyvatsiia patsiienta, yak shliakhy pidvyshchennia rezultatyvnosti fizychnoi terapii pry ortopedychnykh porushenniakh [Management and Motivation of Patients as a Way of Increasing the Efficiency of Physical Therapy in Orthopedic Disorders]. Ukrainskyi zhurnal medytsyny, biolohii ta sportu, 4(5), 295-302. https://doi.org/10.26693/ imbs04.05.295 [in Ukrainian].

[5] Feshchenko, Yu. I., Mostovoy, Yu. M., \& Babiychuk, Yu. V. (2002). Protsedura adaptatsii mizhnarodnoho opytuvalnyka otsinky yakosti zhyttia MOS SF-36 v Ukraini. Dosvid zastosuvannia u khvorykh bronkhialnoiu astmoiu [The procedure of adaptation of international quality of life questionnaire MOS SF-36 in Ukraine. The experience of administration in asthma patients]. Ukrainskyi pulmonolohichnyi zhurnal, (3), 9-11. [in Ukrainian].

[6] Guo, H. R., Tanaka, S., Halperin, W. E., \& Cameron, L. L. (1999). Back pain prevalence in US industry and estimates of lost workdays. American Journal of Public Health, 89(7), 1029-1035. https://doi. org/10.2105/aiph.89.7.1029

[7] Kalashnikov, N. A., \& Kunitsa, S. N. (2015). Aspekty vzaimodeistviya patsienta i vracha, vozmozhnost' ikh optimizatsii v meditsinskoi praktike (Chast' 2) [Aspects of the interaction between a patient and a doctor the possibility of their optimization in medical practice (Part 2)]. Therapia, (7-8), 36-39. http://medlib.dp.gov.ua//irbis2/images/fond publications/therapia/Therapia 2015 7-8.pdf. [in Russian].

[8] Kelsey, J. L., White, A. A., Pastides, H., \& Bisbee, GE. Jr. (1979). The impact of musculoskeletal disorders on the population of the United States. The Journal of Bone and Joint surgery. American Volume, 61(7) 959-964. https://europepmc.org/article/med/158597

[9] Palazzo, C., Ravaud, J. -F., Papelard, A., Ravaud, P., \& Poiraudeau, S. (2014). The Burden of Musculoskeletal Conditions. PLOS ONE, 9(3), Article e90633. https://doi.org/10.1371/journal. pone. 0090633

[10] Palazzo, C., Ravaud, J. -F., Trinquart, L., Dalichampt, M., Ravaud, P., \& Poiraudeau, S. (2012). Respective Contribution of Chronic Conditions to Disability in France: Results from the National Disability-Health Survey. PLOS ONE, 7(9), Article e44994. https://doi.org/10.1371/ journal.pone.0044994

[11] Picavet, H. S. J. \& Hoeymans, N. (2004). Health related quality of life in multiple musculoskeletal diseases: SF-36 and EQ-5D in the DMC3 study. Annals of the Rheumatic Diseases, 63(6), 723-729. https://doi. org/10.1136/ard.2003.010769

[12] Raad, A. H. M. A., Vitomsky, V., Jafar T., \& Nikanorov, O. (2017). Vidnovlennia funktsionalnykh pokaznykiv nyzhnoi kintsivky ta yakosti zhyttia pislia operatyvnoho likuvannia rozryvu akhillovoho sukhozhylka [Restoring lower limb functional parameters and quality of life after surgical treatment of Achilles tendon rupture]. Sportyvna medytsyna i fizychna reabilitatsiia, (1), 79-87. [in Ukrainian].

[13] EuroQol Research Foundation (2019, September). EQ-5D-5L User Guide. Version 3.0. https://eurogol.org/publications/user-quides.

[14] Ritvo, P. G., Fischer, J. S., Miller, D. M., Andrews, H., Paty, D. W., \& LaRocca, N. G. (1997). Multiple Sclerosis Quality of Life Inventory: A User's Manual. National Multiple Sclerosis Society. https://www. nationalmssociety.org/NationalMSSociety/media/MSNationalFiles. Brochures/MSQLI -A-User-s-Manual.pdf

[15] Roux, C. H., Guillemin, F., Boini, S., Longuetaud, F., Arnault, N., Hercberg, S., \& Briançon, S. (2005). Impact of musculoskeletal disorders on quality of life: an inception cohort study. Annals of the rheumatic diseases, 64(4), 606-611. https:///doi.org/10.1136/ard.2004.020784

[16] Scherbakova, A. M., \& Gudilina, O. N. (2010). Sravnitel'naya kharakteristika otnosheniya $\mathrm{k}$ ogranichennym vozmozhnostyam svoego zdorov'ya lits s vrozhdennymi i priobretennymi narusheniyam statodinamicheskoi funktsii [The Comparative Characteristics of Attitudes towards the Limited Capabilities of Own Health in People with Congenital and Acquired Disorders of Static-Dynamic Functions] Psikhologicheskaya nauka i obrazovanie, (5), 77-86. [in Russian].

[17] Vitomskyi, V. V., Lazarieva, O. B., Fedorenko, S. M., \& Vitomska, M. V. (2019). Methods of management and motivation in personnel management of the center of physical therapy and improving the quality of services for patients with orthopedic profile at the outpatient stage. Health, sport, rehabilitation, (5), 17-27.

[18] Vitomskyi, V. V., Lazarieva, O. B., Ra'ad, A. H. M. A., \& Vitomska, M. V. (2017). Restoration of ankle joint, quality of life dynamics and assessment of achilles tendon rupture consequences. Pedagogics, psychology, medical-biological problems of physical training and sports, 21(6), 308-314. https://doi.org/10.15561/18189172.2017.0608

[19] Vos, T., Flaxman, A. D., Naghavi, M., Lozano, R., Michaud, C., Ezzati, M., Shibuya, K., Salomon, J. A., Abdalla, S., Aboyans, V., Abraham, J., Ackerman, I., Aggarwal, R., Ahn, S. Y., Ali, M. K., AlMazroa, M. A., Alvarado, M., Anderson, H. R., Anderson, L. M., ... Murray, C. J. (2012). Years lived with disability (YLDs) for 1160 sequelae of 289 diseases and injuries 1990-2010: a systematic analysis for the Global Burden of Disease Study 2010. The Lancet, 380(9859) 2163-2196. https://doi.org/10.1016/s0140-6736(12)61729-2 